\title{
C-N-He-Ar Cycling at the Hikurangi Subduction Margin, New Zealand
}

\author{
GABE S. EPSTEIN $^{1 *}$, GRAY E. BebOUT ${ }^{1}$, BRUCE W. \\ CHRISTENSON ${ }^{2}$, HIROCHIKA SUMINO ${ }^{3}$, IKUKO WADA ${ }^{4}$, \\ CYNTHIA A. WERNER ${ }^{5}$, DAVID R. HILTON ${ }^{6}$ \\ ${ }^{1}$ Dept. of Earth and Environmental Sciences, Lehigh \\ University, Bethlehem, PA, USA (*correspondence: \\ gse216@lehigh.edu) \\ ${ }^{2}$ National Isotope Center, GNS Science, Lower Hutt, NZ \\ ${ }^{3}$ Dept. of Basic Science, University of Tokyo, Tokyo, Japan \\ ${ }^{4}$ Dept. of Earth Sciences, University of Minnesota, \\ Minneapolis, MN, USA \\ ${ }^{5}$ USGS-Contractor, New Plymouth, NZ \\ ${ }^{6}$ Scripps Institution of Oceanography, La Jolla, CA USA
}

We are evaluating the cycling of $\mathrm{C}, \mathrm{N}$, and noble gases at the Hikurangi margin, with $\sim 35$ analyses of gases from across the forearc-arc-backarc and further analyses planned for April-May 2020. We present C-N concentrations and isotope compositions of sediments outboard of the trench and wall-rock metasediment in the Taupo Volcanic Zone (TVZ). We compare these data with noble gas and C-N data for gases from fumaroles and thermal springs. Ongoing work includes thermal modeling, thermodynamic calculations of prograde devolatilization, and estimation of $\mathrm{TVZ} \mathrm{CO}_{2}$ output flux.

The incoming sediment section at IODP Site 1520 consists of uppermost terrigenous trench-fill $(7 \pm 3 \mathrm{wt} . \%$ carbonate, $0.39 \pm 0.17$ wt. $\%$ organic $\mathrm{C}$ ), pelagic sediment (61 \pm 21 wt. $\%$ carbonate, $0.24 \pm 0.15 \mathrm{wt} . \%$ organic C), and lowermost volcaniclastics ( $13 \pm 14 \mathrm{wt} . \%$ carbonate). Isotope compositions are relatively uniform, with $\delta^{15} \mathrm{~N}=+4.4 \pm 0.9 \%$ (AIR), $\delta^{13} \mathrm{C}_{\text {carb }}=+0.9 \pm 1.1 \%$ (VPDB), and $\delta^{13} \mathrm{C}_{\text {red }}=-25.9 \pm$ $1.2 \%$ (VPDB). Wall-rock metasediments have $\delta^{15} \mathrm{~N}=+2.4$ to $+6.4 \%$ o, $\delta^{13} \mathrm{C}_{\text {red }}=-25.0 \pm 1.9 \%$. Trench-fill sediments are largely removed by accretion, thus the carbonate-rich section likely contributes more to the gas emissions.

The dominant $\mathrm{C}$-bearing gas phase in the forearc is $\mathrm{CH}_{4}$ $\left(\delta^{13} \mathrm{C}=-35\right.$ to $-53 \%$ o) and that within the TVZ gases is $\mathrm{CO}_{2}$ $\left(\delta^{13} \mathrm{C}=-2\right.$ to $\left.-10 \%\right)$. Forearc noble gas ratios have crustal to atmospheric values $\left( \pm\right.$ minor mantle contribution; ${ }^{3} \mathrm{He} /{ }^{4} \mathrm{He}=$ 0.2-1.7 $\mathrm{R}_{\mathrm{A}}$ and ${ }^{40} \mathrm{Ar}{ }^{36} \mathrm{Ar} \geq 296$ ), while $\mathrm{He}-\mathrm{Ar}$ and $\mathrm{C}-\mathrm{N}$ isotope values of gases from the TVZ are consistent with mantle and recycled sedimentary contributions $\left({ }^{3} \mathrm{He} /{ }^{4} \mathrm{He}=4\right.$ $7 \mathrm{R}_{\mathrm{A}}, \delta^{15} \mathrm{~N}=+1.3 \pm 0.9 \%$, and $\left[\mathrm{N}_{2} /{ }^{\beta 6} \mathrm{Ar}\right] / \mathrm{AIR}=1-10$ ). Overlap in $\delta^{13} \mathrm{C}_{\text {red }}$ and $\delta^{15} \mathrm{~N}$ of incoming sediments and wall rocks complicates differentiation of $\mathrm{C}$ sources but, given the accretion of the trench-fill sequence, the apparent sedimentderived $\mathrm{C}_{\text {org }}$ component $(\approx 30 \%$, after [1]) and $\mathrm{N}$ in the gases could reflect contamination by Torlesse/Waipapa wall rocks.

[1] Sano \& Marty (1995) Chem. Geol. 119, 265-274. 